\title{
Increasing biogas production of rumen fluid using cattle manure collected at different time as a substrate
}

\author{
Rabiu, A. ${ }^{1}$, Yaakub, H. ${ }^{1}$, Liang, J. B. ${ }^{2}$, and Samsudin, A. A. ${ }^{1,2^{*}}$ \\ ${ }^{1}$ Department of Animal Science, Faculty of Agriculture, Universiti Putra Malaysia, 43400 Serdang, Selangor, \\ Malaysia. \\ ${ }^{2}$ Institute of Tropical Agriculture, Universiti Putra Malaysia, 43400 Serdang, Selangor, Malaysia.
}

\begin{abstract}
The effect of cattle manure collected at different time inoculated with rumen fluid of cattle on biogas production at mesophilic condition was evaluated. A laboratory experiment was carried out using $1000 \mathrm{ml}$ biodigester and performed in batch operation mode. Approximately 100 grams of fresh cattle manure $(M)$ was assigned to each biodigester and mixed with rumen fluid $(R)$ and distilled water $(W)$ into three different $M: W: R$ ratio; 1:1:0; 1:0.5:0.5; and 1:0:1 respectively. All the treatments were prepared in triplicates. The $\mathrm{pH}$ of the slurry was recorded before and after the biogas production was determined. The biogas production was recorded at every three days interval for 24 days. The results obtained shows that the $\mathrm{pH}$ of the mixture before and after the biogas production provided a reading of 7.34 and 7.15. Significant different $(P<0.05)$ was observed in the cattle manure collected at $0 \mathrm{~h}$ and $24 \mathrm{~h}$ between the treatment group and control. The best performance biogas production was observed if the rumen fluid used between the ranges of 25-50\% of rumen fluid. Cattle manure collected after $12 \mathrm{~h}$ of defecation recorded with the highest biogas production compared to $0 \mathrm{~h}$ and $24 \mathrm{~h}$ of cattle post-defecation. The highest biogas produced was recorded in $T 3$ throughout the experimental periods.
\end{abstract}

Keywords: rumen fluid, inoculums, biogas, mesophilic condition

\section{Introduction}

Livestock waste is an important source of greenhouse gas emissions, particularly in developed countries where large numbers of animals are intensively kept in housed. Biogas is a term used to represent a mixture of different gases produced as a result of the conversion of volatile solids by the action of anaerobic micro-organisms on domestic and agricultural waste [1]. The biogas production is limited by the amount of volatile solids added to the digester. It usually contains $50 \%$ and above methane $\left(\mathrm{CH}_{4}\right)$ and other gases in relatively low proportions namely, $\mathrm{CO}_{2}, \mathrm{H}_{2}, \mathrm{~N}_{2}$ and $\mathrm{O}_{2}$ [2]. Most of the organic acids and all of the $\mathrm{H}_{2}$ are metabolized by methanogens, with the end result being production of a mixture of approximately $55 \%$ to $70 \% \mathrm{CH}_{4}$ and $30 \%$ to $45 \% \mathrm{CO}_{2}$, called biogas. The mixture of the gases is combustible if the methane content is more than $50 \%$ [3]. The methanogens are slower growing and more environmentally sensitive to $\mathrm{pH}$, air, and temperatures than the acidogenic bacteria. Usually, the methanogens require a narrow $\mathrm{pH}$ range (above 6), temperatures at or above $21^{\circ} \mathrm{C}$, and adequate time (usually more than 15 days), to most effectively convert organic acids into biogas [4]. Anaerobic digestion may be seen as a technology that are widely used in the treatment of organic waste for biogas production. It is a natural process in which bacteria convert organic materials into biogas. This technology utilizes manure for biogas production and it is one of the most promising uses of biomass wastes as it provides a source of energy and at the same time resolving ecological and agrochemical issues [5]. The process occurs in an anaerobic (oxygen-free) environment through the activities of acid- and methane-forming bacteria that break down the organic material and produce $\mathrm{CH}_{4}$ and $\mathrm{CO}_{2}$ in a gaseous form. A number of studies has been conducted to increase biogas yield in the anaerobic digestion. An attempt to improve the biomass conversion efficiency and biogas yield are abundant which include; pretreatment of manure by separating solids from digested materials [6]; improving substrate composition by co-digesting with other substrate [7]; improving contact between bacteria and substrate using stirring [8]; and improving nutritional requirements of the bacterial population in the biodigester [9]. To our best knowledge, the information of biogas production of different levels of rumen fluid using cattle manure collected at different time as a substrate is rather limited. Therefore the aim of the current work was to determine the effective time of using the cattle manure as substrate for biogas production. 


\subsection{Sample preparation}

\section{Materials and Methods}

Both cattle manure and the rumen fluids used in this research were taken from a teaching abattoir located at Department of Animal Science, Faculty of Agriculture, Universiti Putra Malaysia. The animals were fed with basal diet containing of $60 \%$ roughages and $40 \%$ of concentrates based on daily intake of $3 \%$ DM per bodyweight. Approximately, $2 \mathrm{~kg}$ of rumen content was homogenized mixed with 15 liters of distilled water. The solid content is then separated from the slurry by a filter sieve before adding the cattle manure. The manure was collected at three different time; $0 \mathrm{~h}, 12 \mathrm{~h}$ and $24 \mathrm{~h}$ respectively. The manure and rumen fluids sample collected were manually homogenized to ensure proper mixture of all the contents. The $\mathrm{pH}$ of the mixture was recorded.

\subsection{Experimental apparatus set up}

A laboratory test of $1000 \mathrm{ml}$ biodigester was operated in batch operating system. The experimental apparatus consists of biodigester and biogas measurement. The biodigester was made from conical flask bottle that are tightly plugged with rubber stopper and equipped with valve for biogas measurement. The temperature of mixture was maintained between $34^{0} \mathrm{C}$ to $38^{0} \mathrm{C}$ value thermostatically controlled electrically by heated water bath. Biogas formed was measured by using 'liquid displacement method' as described previously by [5].

\subsection{Experimental design and procedure}

Approximately 100 gram of cattle manure (M) was used as substrate. Approximately 100 gram of the manure collected at three different time were fed into each biodigester and mixed with rumen fluid (R) and distilled water (W) into three different treatment groups (M: W: R); T1 (1:1:0) control; T2 (1:0.5:0.5); and T3 (1:0:1) that are correspond to $0 ; 25 ; 50 \%$ of rumen fluid, respectively (Table 1). The composition of the substrates and inoculums used in this study is presented in Table 1. Prior to experiment, the biodigester was flushed with $\mathrm{CO}_{2}$ to provide an anaerobic condition. Biogas formed was measured at every at every three days interval for 24 days All of the samples in this experiment were run in triplicates. Significance differences between treatments and control were determined statistically using SAS by Dunnet.

Table 1: Three different M: W: R ratio contents

\begin{tabular}{llcccc}
\hline & M:W:R ratio & MANURE $(\mathbf{g})$ & WATER $(\mathbf{m l})$ & RUMEN $(\mathbf{m l})$ & RUMEN \\
\hline T1 & $1: 1: 0$ & 100 & 100 & 0 & 0 \\
T2 & $1: 0.5: 0.5$ & 100 & 50 & 50 & 25 \\
T3 & $1: 0: 1$ & 100 & 0 & 100 & 50 \\
\hline
\end{tabular}

Keys: $\mathrm{M}=$ manure; $\mathrm{W}=$ water; $\mathrm{R}=$ rumen fluid.

\section{Result and Discussion}

The $\mathrm{pH}$ of the mixture before and after the biogas production experiment provided a reading of 7.34 and 7.15. Measured $\mathrm{pH}$ values are close to neutral. [10] reported that the $\mathrm{pH}$ of a normal and healthy anaerobic digestion system is generally in the range of 6.5 to 8.5. Under normal conditions, the digestion process balances excess acidity or alkalinity on its own. In general, substrates consist of manure and rumen (25 to $50 \% \mathrm{R})$ exhibit higher cumulative biogas production than substrates contain manure and water only $(0 \%$ $\mathrm{R})$. In other words, specific biogas production per $\mathrm{ml}$ of rumen fluid mixed with the manure is higher than the sample that does not contain the rumen fluid. Significant different $(\mathrm{P}<0.05)$ was observed in the cattle manure collected at $0 \mathrm{~h}$ and $24 \mathrm{~h}$ between the treatment group and control (Fig. 1). However, the similar result was not observed in the cattle manure collected at $12 \mathrm{~h}$ where the biogas produced in $\mathrm{T} 2(25 \% \mathrm{R})$ was somewhat similar with T1 (0\% R) (Fig. 2).

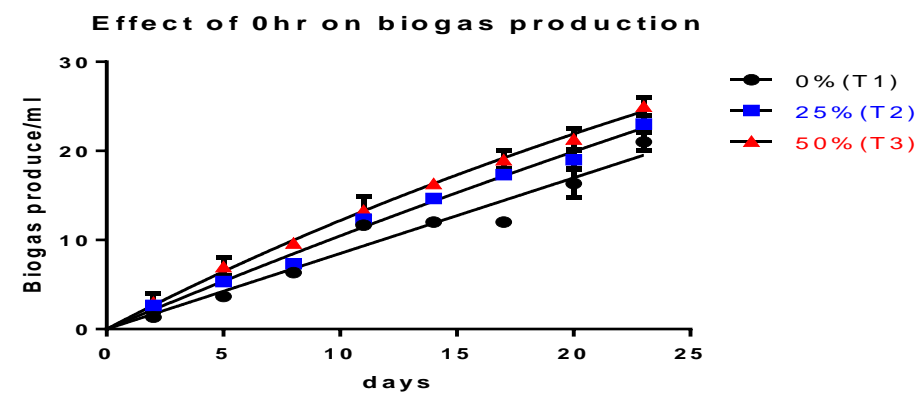

Figure 1: Biogas production from cattle manure collected at $0 \mathrm{~h}$. 
Cattle manure collected after $12 \mathrm{~h}$ of defecation recorded with the highest biogas production compared to $0 \mathrm{~h}$ and $24 \mathrm{~h}$ of cattle post-defecation (Fig. 2). The highest biogas produced was recorded in T3 throughout the experimental periods (Fig. 2). In this treatment group, the least biogas produced was recorded in $0 \mathrm{~h}$ with less than $25 \mathrm{ml}$ being produced while the highest was in $12 \mathrm{~h}$ with $37 \mathrm{ml}$ of biogas produced. The biogas production in $0 \mathrm{~h}$ was slowly increased form day to day (Fig. 1). Unlike $0 \mathrm{~h}$, cattle manure collected at $12 \mathrm{~h}$ and $24 \mathrm{~h}$ demonstrate rapid production of biogas with more than $10 \mathrm{ml}$ of biogas being produced in less than three days in all treatment groups except for $\mathrm{T} 1$ in cattle manure collected at $24 \mathrm{~h}$ (Fig. 3). In this study, the biogas produced in all of the treatment groups increased as observation days increased which corroborated with the findings of [11] that observed a very slow rate of biogas being produce at the beginning of the experiment. At the beginning (first few days) biogas production was higher and peaked about 15 to $17 \mathrm{~mL}$ in cattle manure collected at $12 \mathrm{~h}$ and $24 \mathrm{~h}$ at day 3 . This was because of digestion of the readily biodegradable organic matter in the manure and inoculum mixture. Later the gas production started to reduces due to the fading out of the readily degradable organic matter at day 10 and this period termed as lag phase or starting up. The lag phase is the time required to initiate the biogas production while the microorganism (bacteria) get used to with the digestion environment, and microorganism and manure mix get assimilated. This is predicted due to the biogas production rate in batch condition is directly corresponds to specific growth rate of methanogens in the biodigester. [12] whose also reported that no such significant difference $(\mathrm{P}>0.05)$, observed in the volume of biogas produced in the first to third week.

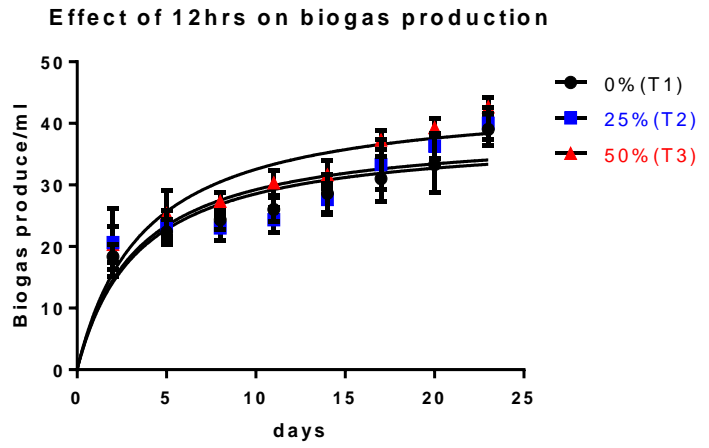

Figure 2: Biogas production from cattle manure collected at $12 \mathrm{~h}$.

In the anaerobic environment, the predominance of $\mathrm{CO}_{2}$ over $\mathrm{CH}_{4}$ in gas production at the initial stage indicated the strong activity of hydrolysis. In contrast, higher $\mathrm{CH}_{4}$ content over $\mathrm{CO}_{2}$ in the gas production implied strong activity of the methanogens [13]. Therefore, biogas production gradually increased until day 10 and stabilized to a value of approximately 30-37 ml of biogas (Fig. 2 and Fig. 3). In general, fresh manure should yields more methane than aged manure but in this study, it is not the case. Our study demonstrated that cattle manure collected at $12 \mathrm{~h}$ yield better results than $0 \mathrm{~h}$ and $24 \mathrm{~h}$. The main reason behind this is remain unclear. However, we speculated that at $12 \mathrm{~h}$, the cattle manure has partially degraded by the microorganisms especially fungi present in surrounding environment while the fresh manure $(0 \mathrm{~h})$ still contain high lignocellulosic materials that could reduce the degradation efficiency of bacteria in the biodigester. On the other hand, the nutrient in the cattle manure collected at $24 \mathrm{~h}$ may have depleted completely thus limiting the bacteria from getting it source of carbon from the nutrient in the manure to produce biogas.

Effect of $24 \mathrm{hrs}$ on biogas production

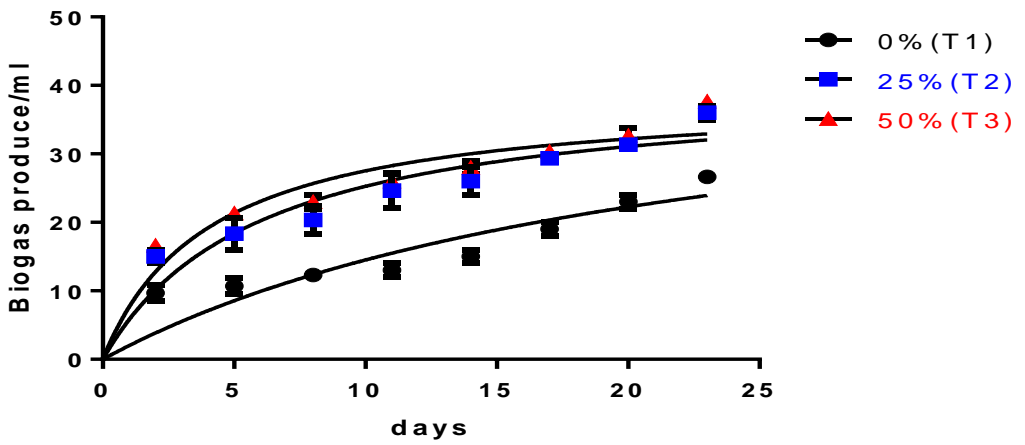

Figure 3: Biogas production from cattle manure collected at $24 \mathrm{~h}$. 
Apart from that, several reasons may also have contributed to the situation; (i) the methanogenic bacteria might not be present in large numbers; (ii) right amount of carbon and hydrogen molecules might not have been present, or (iii) the mixture may not have right amount of water added to it [14]. The lower methane production could also be a result of diet characteristics and may have contained compounds, such as ammonia or VFAs, in concentrations that would inhibit methanogenic activity [15]. High concentration of anaerobic bacteria content in liquid rumen works effectively to degrade organic substrate from manure. Rumen of the ruminant animals contains the highly anaerobic bacteria dominated by cellulolytic bacteria able to biodegrade cellulose material from manure [16]. Moreover, amount of biogas produced seemed proportional to the initial amount of inoculums [17] and the bovine rumen fluid inoculums had a strong effect on anaerobic bio stabilization of fermentable organic fraction of municipal solid waste [18].

\section{Conclusion}

Based on the present study, it can be concluded that cattle manure collected at $12 \mathrm{~h}$ produced higher biogas than cattle manure collected at $0 \mathrm{~h}$ and $24 \mathrm{~h}$. Apart from that, cattle manure inoculated with rumen fluid produced higher biogas than manure inoculated with water. These may be attributed to the activities of the microorganisms present in the rumen fluid that further degrade the remaining nutrient present in the manure. The best performance biogas production was observed if the rumen fluid used between the ranges of $25-50 \%$ of rumen fluid. The utilization of these substrates for biogas production could eliminate its disposal problems and create another abundant source of sustainable energy. The data generated from this study also provide a basis for future work in determining the population of methanogens in those treatment group at different measurement period using molecular approach such as Real-Time PCR. The data from this future analysis will explain why biogas is rapidly or slowly produce throughout the experimental period by evaluating the methanogens population present at specific point of sampling.

\section{References}

[1] Ezeonu S.O., Dioha I.J., and Eboatu A. N., Daily report production from different wastes and identification of methonogenic bacteria involved, Nigerian Journal of Solar Energy 15, 2006, 80-85.

[2] Kalia VC, Sonakya V, and Raizada N, Anaerobic digestion of banana stems waste, Bioresource Technology 73, 2000, 191-193.

[3] Elijah, T. I., I. A. Mangibo, and Y. S. Mohammad, The study of cow dung as co-substrate with rice husk in biogas production, Scientific Research and Essay, 4(9), 2009, 861-866.

[4] Burke, D. A., 2001, Dairy waste anaerobic digestion handbook. Environmental Energy Company, Washington, USA.

[5] Budiyono, Wadiasa, I. N., Johari, S., Sunarso, Increasing biogas production rate from cattle manure using rumen fluid as inoculums, International Journal of Basic \& Applied Sciences, 10(1), 2010, 68-75.

[6] Moller, H. B., A. M. Nielsen, R. Nakakubu and H. J. Olsen, Process performance of Biogas digesters incorporating pre separated manure, Livestock Science, 112, 2008, 217-223.

[7] Gelegenis, J., D. Georgakakis, I. Angelidaki, and V. Mauris 2007, Optimization of biogas production by co-digesting whey with diluted poultry manure, Renewable Energy, 23(13), 2007, 2147-2160.

[8] Kamir, KR. Hoffmann, K. T. Klassonb, and M. H. Al-Dahlan., Anaerobic digestion of animal waste: effect of mode of mixing, Water Research 39, 2005, 3597-3606.

[9] Dermici. G. G. and G. N Demirer, Effect of initial COD concentration, nutrient addition, temperature and microbial acclimation on anaerobic treatability of broiler and cattle manure, Bioresource Technology 93, 2004, 109-117.

[10] Mashandete A, BjOrnsson L, Kivaisi A K, Rubindamayugi M S T, and Mattiasson B., Effect of particle of biogas yield from sisal fiber waste, Renewable Energy, 31, 2006, 2385-2392.

[11] Nopharatana, A., P. C. Pullammanappallil, and W. P. Clarke, Kinetics and dynamic modeling of batch anaerobic digestion of municipal solid waste in a stirred reactor, Waste Management, 27, 2007, 595-603.

[12] Rabah, A. B., Baki, A. S., Hassan, L. G., Musa, M. and Ibrahim, A. D., Production of biogas using abattoir waste at different retention time, Science World Journal, 5(4), 2010, 23-26.

[13] Borhan, M. S., Rahman, S., and Ahn, H. K., Dry anaerobic digestion of fresh feed yard manure: a case study in a laboratory setting, International Journal Emerging Sciences, 2(4), 2012, 509-525.

[14] Prasad, R. D. Empirical study on factors affecting biogas production, ISRN Renewable Energy, Vol 2012, Article ID 136959, 7 pages.

[15] Masse, D. I., Masse, L., Claveau, S., Benchaar, C., and Thomas, O., Methane emission from manure storage, Transaction of the American Society of Agricultural Engineers, 51(5), 2008, 1775-1781.

[16] Aurora, S.P., 1983, Microbial digestion in ruminants. Indian Council of Agricultural Research, New Delhi.

[17] Castillo, R.T., P.L. Luengo, and J.M. Alvarez, Temperature effect on anaerobic of bedding manure in a one phase system at different inoculums concentration, Agriculture, Ecosystems and Environment, 54, 1995, 55-66.

[18] Lopes, W.S., V.D. Leite and S. Prasad, Influence of inoculum on performance of anaerobic reactors for treating municipal solid waste, Bioresource Technology, 94, 2004, 261-266. 